\title{
The Effects of Hedonism and Gender on Liberal Accounting
}

\section{Eko Widodo Lo}

YKPN School of Business, Yogyakarta, Indonesia

e-mail: ewidodolo@gmail.com

\begin{abstract}
This study investigates the influence of hedonism and gender on liberal accounting actions. This research uses a survey method by using questionnaires. Factor analysis results reveal that three questions of hedonism and four questions of liberal accounting are valid. Cronbach's alpha of each variable show that they are reliable. Multiple regression analysis is conducted for examining the research hypotheses. Control variables in the research model are job and education level. Data analysis results indicate that hedonism positively affects liberal accounting. However, the results show that gender does not affect liberal accounting. The research contribution is to relate hedonism and gender with liberal accounting behaviors. This provides new theoretical explanations of liberal accounting behaviors. Study conclusions can be beneficial for deciding the appropriate human characteristics for certain accounting choices.
\end{abstract}

Keywords: Gender, gender socialization theory, hedonism, liberal accounting

\begin{abstract}
Abstrak
Penelitian ini meneliti pengaruh hedonisme dan jenis kelamin terhadap tindakan akuntansi liberal. Penelitian ini menggunakan metode survei dengan menggunakan kuesioner. Hasil analisis faktor menunjukkan bahwa tiga pertanyaan mengenai hedonisme dan empat pertanyaan tentang akuntansi liberal adalah valid. Cronbach alpha setiap variabel menunjukkan bahwa setiap variabel adalah reliabel. Analisis regresi berganda digunakan untuk menguji hipotesis penelitian. Variabel-variabel kendali dalam model penelitian meliputi pekerjaan dan tingkat pendidikan. Hasil analisis data menunjukkan bahwa hedonisme berpengaruh positif terhadap akuntansi liberal. Akan tetapi, hasil analisis juga menunjukkan bahwa jenis kelamin tidak mempengaruhi akuntansi liberal. Kontribusi penelitian ini adalah menghubungkan hedonisme dan jenis kelamin dengan perilaku akuntansi liberal. Hal ini memberikan penjelasan teoritis baru mengenai perilaku akuntansi liberal. Simpulan penelitian ini dapat bermanfaat untuk menentukan karakteristik manusia yang sesuai untuk kebijakan-kebijakan akuntansi tertentu.
\end{abstract}

Kata kunci: Jenis kelamin, gender socialization theory, hedonisme, akuntansi liberal 


\section{INTRODUCTION}

Understanding of human characteristics is an important issue in accounting practices. Characteristics of people drive their behaviors. Globalization and free market cause many products are available in the market. This can drive hedonic consumptions among people, including accountants. Therefore, the impact of hedonic consumption on accounting decisions is very interesting to be investigated. Additionally, the effect of gender variable on accounting decision by accountants is still not understood clearly. Studies about the effects of gender on accounting decisions is still questionable

The purpose of this research is to increase our comprehension of the impacts of human characteristics to accounting practices, specially the influence of hedonism and gender on liberal accounting choices. This study tests whether hedonism behaviors influence liberal accounting practices. Furthermore, the understanding whether males and females have difference judgments on liberal accounting has become critical as more females involve in accounting professions.

This study provides some contributions. First, this study attempts to relate hedonism and gender variables to liberal accounting policy among accountants. This research attempts to give new theoretical explanations of liberal accounting behaviors. Second is practical implication to accounting policies. Conclusions of this study will provide evidence about human characteristics which influence liberal accounting policies.

An agency relationship is a contract in which the principals hire the agents to do some services and delegate some decisionmaking authorities to the agents (Jensen \& Meckling, 1976; Anthony \& Govindarajan, 2007). In an agency relationship, principals and agents are rational and maximize their personal benefits (Eisenhardt, 1989). In an employment agreement, a shareholder is a principal, and an accountant is an agent. Accountants tend to maximize their personal benefits. They will conduct opportunistic behaviors by doing liberal accounting

Cost of transaction theory portends that managers tend to do earnings management by increasing the accounting earnings, to reduce costs of transactions (Bowen et al., 1995; Burgstahler \& Dichev, 1997). This theory states that firm accounting profits will influence the transaction terms between a company and the stakeholders. Terms of transactions will be more favorable for a company with high accounting earnings. An accountant tends to present higher accounting earnings by conducting liberal accounting, to get a favorable transaction term.

Liberal accounting is an optimistic view in facing business uncertainty by permanently choosing accounting methods, estimations, and real activities manipulations that recognize revenues faster but expenses slower, and value assets higher but liabilities lower (Wolk et al., 2001; Penman, 2001). Examples of liberal accounting policies involve continuously using FIFO cost flow assumption when costs of inventories increase, estimating lower warranty expenses, and giving more lenient credit term for sales.

Hedonism states that the people life aim is contentment. Voss et al. (2003) stated that hedonic consumptions refer the proclivity to buy products derived from experience of using them. A synthesis among agency theory, transaction cost theory, and hedonism concept are developed. Agency theory portends that an accountant will do liberal accounting for an opportunistic action. Transaction cost theory predicts that accountants tend to do liberal accounting to reduce costs of transactions. It is predicted that individuals with hedonic consumption will conduct liberal accounting to obtain permanently high income and reputation. 
High income will make possible to conduct hedonic consumptions. Accountants with high hedonic consumption have a proclivity to do liberal accounting. Based on this logical thinking, the hypothesis is as follow:

\section{$\mathrm{H}_{1}$ : Hedonism positively affects liberal accounting}

Theory of gender socialization states that males and females undergo fundamentally different moral development because of their tendency to bring different sets of values in workplace (Clickman et al., 2001). These sets of values shape different attitudes and behaviors of them. Males give more value on money, power, promotion, and tangible measures of personal accomplishment. Females are more cared on helping others and harmonious connections (Betz et al., 1989; Clikeman et al., 2001). Francis et al. (2014) gave strong support for the notion that female CFOs tend to be more risk averse that male CFOs, that leads female CFOs to adopt more conservative reporting decision making. However, Li (2015) found no significant influence of diversity of board gender on conditional accounting conservatism. These findings indicate that there still inconsistency of previous research results. Based on gender socialization theory, it is predicted that males tend choose more liberal accounting than females. The developed hypothesis is as follow:

$\mathrm{H}_{2}$ : Gender influences liberal accounting

\section{METHOD}

Participants in this research are 90 accounting students at a school of business in Indonesia. Accounting students are sufficient surrogates of professional and nonprofessional populations in many decision process research designs (Houghton \& Hronsky, 1993; Tuttle et al., 2002; Locke, 2015). Participants involve accounting students of undergraduate and graduate degrees and an accounting profession education program. This study provides questionnaires to the accounting students who taking or have passed accounting theory subject, so that they understand about liberal accounting policies. Participants are voluntary and the responses to questions are anonymous. There are no grade and no monetary incentives for them. They consist of 60 females and 30 males.

The research model consists of one criterion variable, two main predictor variables, and two control variables. The dependent variable is liberal accounting. Main independent variables consist of hedonism and gender. Control variables involve education level and job. Variables are measured by questionnaires as follow:

1. Hedonism is measured by five items of questions. The questions have a 1 to 7 scale with 1 for strongly disagree, and 7 for strongly agree.

2. Liberal accounting variable are measured by six items of questions. These questions involve two questions about accounting method changes, two questions about accounting estimation changes, and two questions of real activity manipulation. Each question has scales of 1 to 7 with 1 for strongly disagree, and 7 for strongly agree.

3. Gender is measured by non-metric scales ( $1=$ female, and $2=$ male) .

4. Education level and job variables are also measured by using non-metric scales.

This research uses some statistical tools to examine the questionnaire validity and reliability and research hypotheses. Factor analysis is conducted to test the instrument validity. Cronbach's alpha is used to examine the instrument reliability. Multiple regression analysis is done for testing the hypothesis. Liberal accounting is the criterion variable. 
Hedonism and gender are main independent variables. Control variables in this research consist of education level and job. Both are non-metric variables. The multiple regression equation for testing the research hypotheses is as follow:

$$
\mathrm{LA}=\underset{4 \times \mathrm{JOB}+\varepsilon}{\beta \_0+\beta \_1 \times \mathrm{HD}+\beta \_2} \underset{\mathrm{GD}}{0}+\beta \_3 \times \mathrm{EDU}+\beta
$$

Where:LA $=$ Liberal accounting; $\mathrm{HD}=$ Hedonism; GD $=$ Gender ( $1=$ female, $2=$ male $) ; \mathrm{EDU}=$ Education level $(1=$ undergraduate student; $2=$ graduate student or undergraduate degree; $3=$ doctoral student or graduate degree; $4=$ doctoral degree); $\mathrm{JOB}=$ job $(1=$ students, $2=$ lecturers, and $3=$ managers or professionals)

\section{RESULTS AND DISCUSSION}

Questionnaires validity is examined by factor analysis. This is applied on 90 questionnaires. A question which has factor loading score of less than 0.50 is removed. There are three questions are disposed. They involve two questions of hedonism (question 4 and 5) and one question of liberal accounting (question 1). Table 1 reports factor loading of seven usable questions. They consist of three questions of hedonism and four question items of liberal accounting. The factor analysis results indicate that KMO (KaiserMeyer-Olkin) sampling adequacy measure is
0.684. This is higher than 0.60, and Bartlett's test of sphericity has a probability value of 0.000 . Therefore, the next analysis can be conducted.

Table 2 reveals the reliability test results. The two factors which are produced from factor analysis are investigated by Cronbach's alpha. Table 2 reveals the reliability test results. When a Cronbach's alpha is higher than 0.60 , the factor can be concluded as a reliable factor (Sekaran \& Bougie, 2010). The Cronbach's alphas of the two factors are more than 0.60 , they are reliable. This study conducts the mean score of questions which fulfill validity and reliability examinations for further data analysis.

Table 2. Reliability Test

\begin{tabular}{lr}
\hline \multicolumn{1}{c}{ Variable } & \multicolumn{1}{c}{ Cronbach's Alpha } \\
\hline Hedonism & 0.650 \\
Liberal accounting & 0.681 \\
\hline
\end{tabular}

\section{Descriptive Analysis}

Table 3 indicates the scores means and standard deviations of the hedonismandliberal accounting variables. The means of variables are high enough. Scores mean of hedonism variable is 4.2185 . This indicates that participants have tendency to do hedonistic consumption. Liberal accounting variable has a mean of 4.4361 . This figure means that participants prefer liberal accounting to conservative accounting. Hedonism variable

\begin{tabular}{|c|c|c|c|}
\hline & Questions & Factor 1 & Factor 2 \\
\hline HD1: & I often buy additional products although I still have enough. & 0.733 & \\
\hline HD2: & I am interested in purchase things immediately, when a seller gives price discounts. & 0.753 & \\
\hline HD3: & I like to buy the fashionable clothes. & 0.780 & \\
\hline LA2: & I will always capitalize research and development expenditures & & 0.723 \\
\hline LA3: & I will always estimate bad debt lower & & 0.660 \\
\hline LA4: & I always tend to estimate inventory obsolescence loss lower & & 0.734 \\
\hline LA5: & I always tend to provide a lenient credit term sales and grant sales price reductions & & 0.700 \\
\hline
\end{tabular}

Table 1. Matrix of Rotated Component

Notes: HD= Hedonism; LA= Liberal accounting 
scores (1.0684) are more disperse than liberal accounting scores $(0.7928)$.

Table 3. Descriptive Statistics

\begin{tabular}{lcr}
\hline \multicolumn{1}{c}{ Variables } & $\begin{array}{l}\text { Scores } \\
\text { Mean }\end{array}$ & $\begin{array}{l}\text { Standard } \\
\text { Deviation }\end{array}$ \\
\hline Hedonism & 4.2185 & 1.0684 \\
Liberal accounting & 4.4361 & 0.7928 \\
\hline
\end{tabular}

\section{Hypotheses Testing}

Research hypotheses are examined by multiple regression analysis. The results is presented in Table 4. Liberal accounting is the criterion variable. Hypothesis 1 predicts that hedonism variable positively affects liberal accounting. The results support hypothesis 1. The regression coefficient of hedonism is positive $(0.188)$ and the probability value is significant (0.012). Therefore, it is concluded that hedonism positively affects liberal accounting.

Hypothesis 2 states that gender variable influences liberal accounting. Results of multiple regression analysis reject this hypothesis. Regression coefficient of gender variable is positive $(0.062)$ but its probability values is not significant $(0.708)$. This research concludes that gender does not influence liberal accounting.

This study includes education level and job as control variables in the research model. Education level regression coefficient is negative $(-0.624)$ and the probability value is significant (0.002). These results show that education level influences accounting liberal. Specifically, higher levels of education are associated with less liberal accounting level (liberal accounting score mean for undergraduate students $=4.5493$; and graduate students $=4.0132$ ). There is no doctoral degree in the sample. The results indicate that the regression model has controlled for the impact of education level on liberal accounting.

Job variable coefficient is positive (1.103) and its probability value is significant
(0.004). Therefore, it can be concluded that job also affects liberal accounting variable. Liberal accounting score mean for students is 4.4185, professionals or managers are 6.0. There is no lecturer in the sample. These results reveal that the regression equation model in this study has controlled for the effects of job to liberal accounting variable.

Table 4. Multiple Regression Analysis Results

\begin{tabular}{llll}
\hline \multicolumn{1}{c}{$\begin{array}{c}\text { Independent } \\
\text { Variables }\end{array}$} & $\begin{array}{l}\text { Regression } \\
\text { Coefficient }\end{array}$ & T-Value & P-Value \\
\hline Constant & 3.187 & 5.179 & 0.000 \\
Hedonism & 0.188 & 2.569 & 0.012 \\
Gender & 0.062 & 0.376 & 0.708 \\
Education level & -0.624 & -3.280 & 0.002 \\
Job & 1.103 & 2.969 & 0.004 \\
\hline R-squared & 0.213 & & \\
Adjusted & 0.176 & & \\
R-squared & & & \\
F-value & 5.749 (probability value $=0.000)$ \\
\hline
\end{tabular}

\section{CONCLUSION}

The objective of this study is to examine the impacts of hedonism and gender variables on liberal accounting. Descriptive statistics reveal that participants have tendency to do hedonistic consumption. They tend to do liberal accounting than conservative accounting. Results of multiple regression analysis indicate that hedonism variable positively affects liberal accounting, while gender variable does not influence liberal accounting behaviors.

This study has some limitations. First, this research emphasizes only on two main predictor variables, namely hedonism and gender. Future work should consider the influence of other predictor, or moderating, or mediating variables, such as human capital. Second, the sampling process is not conducted by using a random basis. Thus, future research should explore whether conclusion of this research can be generalized. 
This study has practical implications for knowing human characteristics of accountants that affect accounting policies. First, the findings reveal that hedonism positively affect liberal accounting. This suggests that company owners or top management should consider hedonism variable when selecting accountants. If there is a greater preference to conduct liberal accounting policies, then managers should consider choosing an accountant with high hedonistic behaviors. On the other hand, when liberal accounting is considered as unethical actions, then they should choose an accountant with low hedonistic behaviors. Second, results show that gender variable does not influence liberal accounting. This means that firms owners and top management do not need to consider gender variable when conducting liberal or conservative accounting policies.

\section{REFERENCES}

Anthony, R. N. \& Govindarajan, V. (2007). Management Control System. Twelfth Edition Singapore: McGraw-Hill/Irwin.

Betz, M., O'Connell, L., \& Shepard, J. M. (1989). Gender differences in proclivity for unethical behavior. Journal of Business Ethics, 8, 321324.

Bowen, R.M., DuCharme, L., \& Shores, D. (1995). Stakeholders' implicit claims and accounting choice. Journal of Accounting and Economics, 20, 255295.

Burgstahler, D. \& Dichev, I. (1997). Earnings management to avoid earnings decreases and loses. Journal of Accounting and Economics, 24, 99126.

Clikeman, P. M., M. A. Geiger, \& O'Connell B.T. (2001). Student perceptions of earnings management: The effects of national origin and gender. Teaching Business Ethics, 5(4),389-410.

Eisenhardt, K. M. (1989). Agency theory: an assessment and review. The Academy of Management Review, 14, 57-74.

Francis, B., Hasan, I., Jong, C. P. \& Qiang, W. (2014). Gender differences in financial reporting decisionmaking: Evidence from accounting conservatism. Bank of Finland Research Discussion Papers.

Houghton K.A. \& Hronsky, J.J.F. (1993). The sharing of meaning between accounting students and members of the accounting profession. Accounting and Finance, November, 131-147.

Jensen, M. C. \& W. H. Meckling, W. H. (1976). Theory of the firm: Managerial behavior, agency costs and ownership structure. Journal of Financial Economics, 3(4), 305-360.

Li, W. (2015). Board gender diversity and accounting conservatism: Evidence from Finland. Thesis. Oulu Business School.

Locke, J. (2015). Interactive data and retail investor decision-making: an experimental study. Accounting and Finance, 55, 213-240.

Penman, H.P. (2001). Financial Statement Analysis and Security Valuation. Singapore: McGraw-Hill Book Co.

Sekaran, U. \& Bougie, R. (2010). Research Methods for Business: A Skill Building Approach. West Sussex: John Wiley \& Son Ltd.

Tuttle, B., Coller, M. \& Plumlee, R. D. (2002), The effect of misstatements on decisions of financial statement users: an experimental investigation of auditor materiality threshold. Auditing: A Journal of Practice and Theory, 21, 11-27. 
Voss, K.E., Spangenberg, E.R., \& Grohmann, B. (2003). Measuring the hedonic and utilitarian dimensions of consumer attitude. Journal of Marketing Research, 40(August), 310-320.

Wolk, H.I., Tearney,M. G. \& Dodd, J. L.. (2001). Accounting Theory: A Conceptual and Institutional Approach. Fifth Edition. Ohia: South-Western College Publishing. 
